\title{
PENGEMBANGAN ASESMEN ALTERNATIF DALAM PEMBELAJARAN MATEMATIKA DENGAN PENDEKATAN REALISTIK DI SEKOLAH DASAR
}

\author{
Fatimab Setiani \\ STKIP Muhammadiyah Sampit \\ Jl. Padat Karya No 3 Baamang Hilir Sampit Kalimantan Tengah \\ fatimah.setiani@yahoo.co.id
}

\begin{abstract}
Abstrak
Tujuan penelitian ini adalah untuk mengembangkan dan menemukan asesmen alternatif yang valid, praktis dan efektif berlandaskan pembelajaran matematika dengan pendekatan realistik di Sekolah Dasar (SD). Penelitian ini merupakan penelitian pengembangan yang mengacu pada model pengembangan pendidikan dari Plomp dengan mengacu pada kriteria kualitas produk pengembangan yang dikemukakan Nieveen, yang meliputi kriteria kevalidan, kepraktisan, dan keefektifan. Hasil penelitian ini adalah seperangkat penilaian dalam pembelajaran matematika dengan pendekatan realistik. Hasil uji coba, menunjukkan bahwa asesmen alternatif telah memenuhi kriteria kevalidan, kepraktisan, dan keefektifan. Kevalidan asesmen alternatif beserta perangkat asesmen yang digunakan termasuk dalam kategori sangat baik. Kepraktisan dan keefektifan asesmen alternatif beserta seluruh perangkat asesmen yang digunakan dalam pelaksanaan asesmen di dalam kelas termasuk kategori sangat praktis dan efektif. Ketercapaian keefektifan asesmen alternatif berdasarkan proses dan hasil pembelajaran cenderung meningkat dengan kategori baik. Demikian juga respons siswa dan guru terhadap penerapan asesmen alternatif yang cenderung positif.
\end{abstract}

Kata kunci: asesmen alternatif, pendekatan realistik. 


\title{
DEVELOPING ALTERNATIVE ASSESMENT IN MATHEMATICS LEARNING USING THE REALISTIC APPROACH IN ELEMENTARY SCHOOLS
}

\author{
Fatimah Setiani \\ STKIP Muhammadiyah Sampit \\ Jl. Padat Karya No 3 Baamang Hilir Sampit Kalimantan Tengah \\ fatimah.setiani@yahoo.co.id
}

\begin{abstract}
This study aimed to develop and generate a valid, practical and effective alternative assessment based on the principle of mathematics learning using the realistic approach in elementary schools (Sekolah Dasar, SD). This study was a research and development study which referred to the model of educational development by Plomp based on the criteria of product quality proposed by Nieveen, including the criteria of validity, practicality, and effectiveness. This study produced a set of assessment in mathematics learning using realistic approach. Based on the result of the tryout, the generated alternative assessment has fulfilled the criteria of validity, practicality, and effectiveness. The validity of alternative assessment and its assessment sets are in very good category. The result of the testing shows that the alternative assessment is very practical and effective, in terms of the learning process and learning achievement which tend to improve toward the good category. The response of students and teachers towards the implementation of this alternative assessment is also positive.
\end{abstract}

Keywords: alternative assessment, realistic approach 
Jurnal Penelitian dan Evaluasi Pendidikan

\section{Pendahuluan}

Matematika sebagai salah satu mata pelajaran di Sekolah Dasar (SD)/ Madrasah Ibtidaiyah (MI) memberi tekanan pada keterampilan berhitung serta pengembangan pengetahuan dasar matematika sebagai bekal belajar lebih lanjut di Sekolah Menengah Pertama (SMP). Meskipun usaha-usaha tersebut tidak berhenti dilakukan dan telah beberapa puluhan tahun dilaksanakan, namun usaha-usaha tersebut masih belum menampakkan hasil yang diharapkan bahkan hasil pembelajaran terkesan sangat rendah, baik ditingkat nasional maupun internasional.

Oleh sebab itu, pembelajaran matematika perlu dilakukan perubahan yang mendasar. Terkait dengan perubahan ini, perlu adanya paradigma baru dalam upaya meningkatkan kualitas pembelajaran matematika. Upaya meningkatkan kualitas pembelajaran matematika dapat ditempuh melalui perbaikan proses pembelajaran di sekolah. Salah satu alternatif inovatif yang dapat diharapkan meningkatkan kualitas pembelajaran matematika adalah pembelajaran matematika realistik yang disebut juga Realistic Mathematics Education (RME).

RME di Indonesia diberi nama Pendidikan Matematika Realistik Indonesia, disingkat PMRI yang dicanangkan pada bulan Agustus 2002 (Marpaung, 2006). Pendekatan ini mula-mula dikembangkan di Negeri Belanda yang sudah melalui proses uji coba selama lebih dari 30 tahun dan telah berhasil diterapkan. PMRI sebagai gerakan pembaharuan pembelajaran matematika di Indonesia dimulai uji coba pada tahun 2001 dimulai dari SD/MI secara bertahap. PMRI telah berhasil diujicobakan dan penerapannya ditawarkan pada sekolah-sekolah yang berminat dan bergabung untuk mengembangkannya. Implementasi PMRI sudah berjalan kurang lebih delapan tahun di Indonesia.Terdapat beberapa permasalahan yang terkait dengan upaya implementasi PMRI.

Berdasarkan data empirik selama uji coba PMRI di samping mempunyai kelebihan-kelebihan, juga mempunyai kelemahan-kelemahan. Salah satu kelemahan dalam implementasi PMRI berdasarkan pengalaman Ratini, Rumgayatri dan Siti Mustaqimah (2001: 4) dalam uji coba PMRI di MIN Yogyakarta II yaitu belum adanya pedoman penilaian, sehingga guru 
merasa kesulitan dalam evaluasi/memberi nilai. Di sisi lain, implementasi PMRI di beberapa SD menunjukkan hasil yang positif. Guru yang telah menggunakan PMRI dalam pembelajaran matematika di sekolah mereka melaporkan hasil yang positif, antara lain: pembelajaran menjadi menyenangkan, siswa menjadi termotivasi, bekerja sama, dan saling menghargai (Buletin PMRI, Edisi I Juni 2003 \& Buletin PMRI, Edisi III Januari 2004). Selain hasil positif yang dirasakan guru, dalam pelaksanakan uji coba guruguru juga menemukan kendala-kendala. Menurut Hadi (2005: 153) salah satu kendalanya adalah tidak adanya standar penilaian sehingga sukar menilai hasil belajar anak.

Hasil prasurvei yang dilakukan peneliti di SDN Timbulharjo, SDN Gambiranom, dan MIN Yogyakarta I mendukung kesimpulan di atas. Peneliti menemukan bahwa: (1) guru merasa kesulitan melakukan penilaian hasil belajar siswa berdasarkan prinsip-prinsip dan karakteristik penilaian dalam PMRI ; (2) belum adanya pedoman yang dapat dijadikan pegangan guru untuk melakukan penilaian hasil belajar anak yang relevan dengan PMRI; (3) guru pada umumnya melakukan penilaian sama dengan mata pelajaran yang lain; (4) penilaian berorientasi pada produk bukan pada proses ; (5) guru jarang melibatkan siswa dalam proses penilaian diri mereka pada tugas-tugas yang diberikan; dan (6) guru jarang memberikan umpan balik (feedback) dan remedial.

Berpangkal tolak dari kondisi tersebut, perlu adanya inovasi model pembelajaran dan pembaharuan dalam penilaian pembelajarannya. Pembelajaran matematika dengan PMRI sebagai salah satu alternatif dari sekian banyak pendekatan dan sudah diimplementasikan kurang lebih sepuluh tahun berjalan, sedangkan asesmen yang dibutuhkan adalah asesmen yang relevan dengan pendekatan pembelajarannya, sehingga dapat meningkatkan kualitas proses dan hasil pembelajaran. Oleh karena itu, perlu dikembangkan asesmen alternatif yang berbeda dengan asesmen yang lazim, yaitu sangat atau terutama menekankan penilaian prosedur atau proses, dan hasil asesmen proses itu dikuantifikasikan. Dengan demikian, diharapkan asesmen alternatif yang dikembangkan betul-betul memiliki kontribusi untuk meningkatkan kualitas pembelajaran matematika, yang akhirnya diharapkan dapat meningkatkan kualitas pendidikan matematika pada umumnya. 
Adapun yang menjadi tujuan dalam penelitian pengembangan ini adalah"menemukan asesmen alternatif yang valid, praktis, dan efektif yang dikembangkan berlandaskan pembelajaran matematika dengan pendekatan realistik di Sekolah Dasar".

Asesmen alternatif mengintegrasikan kegiatan pengukuran hasil belajar dengan keseluruhan proses pembelajaran, bahkan asesmen itu sendiri merupakan bagian yang tidak terpisahkan dari keseluruhan proses pembelajaran. Dengan asesmen alternatif ini, diharapkan proses pengukuran hasil belajar tidak lagi dianggap sebagai kegiatan yang tidak menarik dan bukan merupakan bagian yang terpisah dari proses pembelajaran.

Menurut Hatfield, et al. (2003: 77), karakteristik asesmen alternatif :

a. Students perform, create, and produce.

b. Tasks require problem solving or higher-order thinking.

c. Problems are contextualized.

d. Tasks are often time-consuming and need days to complete.

e. Scoring rubrics or scoring guides are required.

Selanjutnya, menurut Herman, Aschbacher \& Winters (1992: 6) secara umum karakteristik asesmen alternatif :

a. Ask students to perform, create, produce, or do sometbing.

b. Tap higher-level thinking and problem-solving skills.

c. Use tasks that represent meaningful instructional activities.

d. Invoke real-world applications.

e. People, not machines, do the scoring, using human judgment.

f. Require new instructional and assessment roles for teacher.

Dengan demikian, karakteristik utama asesmen alternatif tidak hanya mengukur hasil belajar siswa akan tetapi juga memberikan secara lengkap informasi yang lebih jelas tentang proses pembelajaran. Dengan demikian, asesmen alternatif pada dasarnya dilakukan dengan tujuan untuk menyediakan data secara terus menerus tentang kinerja siswa yang sesungguhya dalam rangka (1) meningkatkan pengalaman belajar; (2) memastikan kompetensi siswa; dan (3) menjadi sumber informasi untuk meningkatkan pembelajaran.

Adapun komponen-komponen asesmen alternatif yang dikembangkan meliputi: (1) Asesmen Perilaku/Aktivitas Siswa, 2) Penilaian Diri (Self- 
assessment), dan (3) Asesmen Kemampuan Pemecahan Masalah melalui Tugas Pekerjaan Rumah (take-home task),

Penilaian perilaku/aktivitas selain menggunakan kuesioner, juga dapat dilakukan melalui observasi perilaku/aktivitas. Observasi perilaku/aktivitas siswa selama pembelajaran, memungkinan seorang guru memiliki informasi yang memadai tentang kemampuan dan keterampilan yang dimiliki oleh para siswanya. Guru akan memperoleh gambaran yang jelas tentang masalah-masalah yang dihadapi oleh siswa berkaitan dengan proses pembelajaran, jika pengamatan dilaksanakan seiring dengan proses pembelajaran. Dengan demikian, hasil observasi aktivitas dapat dijadikan sebagai umpan balik untuk meningkatkan proses pembelajaran.

Sehubungan dengan observasi sebagai sebuah metode dalam asesmen, Freudenthal (1973: 84) menyatakan "...we know that is more informative to observe a student during his mathematical activity than to grade papers". Selanjutnya, Ter Heege (1978: 82) menyatakan "Observation, even though they are mere impression caught by the expert teacher during a lesson, can provide a rather complete picture of the learning process".

Dengan demikian, observasi untuk mengases proses belajar matematika memberikan informasi yang lengkap. Hal ini didukung oleh perkataan Freudenthal (1981: 137) yang menyatakan lebih menekankan proses dari pada produk dalam belajar matematika. Dengan demikian, dalam pengembangan asesmen RME menetapkan bahwa observasi merupakan metode asesmen yang diprioritaskan untuk mengases proses belajar. Hal ini didukung oleh Van den Heuvel-Panhuizen (1996: 17), yang mengatakan bahwa prioritas utama penilaian dalam pendidikan matematika adalah observasi. Observasi harus dilakukan secara kontinu selama proses pembelajaran, sehingga diperoleh informasi yang memadai dan komprehensip tentang perilaku siswa selama proses pembelajaran. Pendapat tersebut, senada dengan pendapat Freudenthal (Van den Heuvel-Panhuizen, 1996: 27), yang mengatakan bahwa untuk memperbaiki penilaian harus dimulai dari micro-environment, yaitu dengan menolong para guru untuk belajar mengamati proses pembelajaran. Belajar untuk mengamati proses pembelajaran merupakan salah satu prinsip semua pelajaran dalam pendidikan matematika. 
Observasi perilaku/aktivitas dilakukan oleh guru pada proses pembelajaran di kelas dengan menggunakan lembar pengamatan aktivitas siswa (LPAS) Observasi perilaku siswa disusun untuk mengetahui perilaku siswa selama pembelajaran. Lembar pengamatan dirancang untuk mengamati perilaku siswa selama pembelajaran termasuk dalam mengerjakan tugastugas yang diberikan di dalam kelas. Lembar pengamatan ini dipegang oleh guru. Namun, untuk keperluan penelitian ini, lembar ini juga dipegang oleh pengamat dalam rangka mendapatkan data untuk menghitung reliabilitasnya.

Penilaian diri (self-assessment) merupakan bentuk penilaian otentik yang penting untuk dilakukan di kelas sebagaimana diungkapkan oleh Pearson Education Development Group (2003). Reys, Suydam, Linquist \& Smith (1998: 56), mengatakan bahwa siswa merupakan penilai yang baik (the best assessor) terhadap perasaan dan pekerjaan mereka sendiri. Ketika siswa menilai pekerjaan mereka sendiri, maka tanggung jawab untuk belajar adalah mereka sendiri. Oleh karena itu, guru dapat memulai proses penilaian diri dengan memberi kesempatan siswa untuk melakukan validasi pemikiran mereka sendiri atau jawaban-jawaban hasil pekerjaan mereka. Penilaian diri (self assessment) dalam penelitian ini menggunakan strategi modelling using exemplars. Modelling using exemplars merupakan suatu teknik yang sangat bermanfaat untuk membangun keterampilan penilaian diri siswa. Teknik tersebut, meliputi penggunaan suatu contoh bagian pekerjaan untuk membantu siswa menilai diri mereka sendiri sepanjang proses pembelajaran.

Asesmen kemampuan pemecahan masalah yang dikembangkan dalam penelitian ini adalah melalui tugas pekerjaan rumah (take-home task) yang lazim disebut PR. Tugas Pekerjaan Rumah (Tugas PR) merupakan salah satu bentuk dari metode pemberian tugas yang diartikan sebagai latihan menyelesaikan soal-soal dan adanya pertanggungjawaban dari siswa. Selain itu, dapat pula menyuruh siswa mempelajari terlebih dahulu topik yang akan dibahas, menyuruh mencari bukti lain dari sebuah teorema dan lain-lain.

De Lange (1987: 232-233) menetapkan 5 (lima) prinsip dalam menerapkan Tugas PR tersebut yakni: 
1. The test should improve learning.

2. The test should be such that the candidates show what they know (positive testing).

3. The test should operationalize the goals of the mathematics a curriculum.

4. The quality of the task is not measured in the firtt place by the ability to score it in an objective way.

5. The tests should fit into the usual schoolwork.

Tabel 1. Rubrik Penskoran Tugas Pekerjaan Rumah

\begin{tabular}{|c|c|}
\hline $\begin{array}{l}\text { Komponen } \\
\text { Pemecahan } \\
\text { Masalah }\end{array}$ & Skor \\
\hline $\begin{array}{l}\text { 1. Memahami } \\
\text { masalah }\end{array}$ & $\begin{array}{l}\text { 0: tidak memahami masalah secara keseluruhan } \\
\text { 1: memahami sebagian atau salah interpretasi } \\
\text { 2: memahami masalah secara lengkap }\end{array}$ \\
\hline $\begin{array}{l}\text { 2. Menyusun } \\
\text { rencana } \\
\text { pemecahan } \\
\text { masalah }\end{array}$ & $\begin{array}{l}0: \text { tidak membuat rencana atau rencana tidak sesuai } \\
\text { 1: merencanakan sebagian dengan benar } \\
\text { 2: merencanakan yang mengarah pada penyelesaian yang } \\
\text { benar }\end{array}$ \\
\hline $\begin{array}{l}\text { 3. Melaksanakan } \\
\text { rencana }\end{array}$ & $\begin{array}{l}\text { 0: tidak menjawab atau menjawab salah berdasar rencana } \\
\text { yang tidak sesuai } \\
\text { 1: melaksanakan sebagian sesuai konsep dan prinsip } \\
\text { matematika } \\
\text { 2: melaksanakan berdasarkan konsep dan prinsip } \\
\text { matematika yang benar }\end{array}$ \\
\hline $\begin{array}{l}\text { 4. Mengevaluasi } \\
\text { solusi yang } \\
\text { diperoleh }\end{array}$ & $\begin{array}{l}\text { 0: tidak menguji jawaban } \\
\text { 1: salah menghitung atau benar sebagian tapi dan kurang } \\
\text { ada ide kreatif } \\
\text { 2: menguji jawabannya tersebut pada kondisi dan variabel } \\
\text { yang terdapat pada masalah tersebut, mengujinya pada } \\
\text { pertanyaan, atau melakukan esti-masi untuk } \\
\text { menentukan apakah jawabannya tersebut cukup masuk } \\
\text { akal. Di samping itu memberi banyak jawaban dan ada } \\
\text { orisinalitas idea atau ide kreatif. }\end{array}$ \\
\hline
\end{tabular}


Pengembangan Tugas PR dalam penelitian ini mengacu pada Tugas PR yang mempertimbangkan kelima prinsip yang dikemukakan De Lange di atas. Kriteria yang dipakai sebagai acuan pemberian skor pada Tugas PR merujuk pada rubrik analytic scoring scale yang disusun oleh Charles, Lester, dan O'Daffer (Reys, Suydam, Lindquist, et al., 1988: 59) dan proses pemecahan masalah mengacu pada model Polya seperti dalam Tabel 1.

Terkait dengan hal tersebut, penelitian ini bertujuan untuk mengembangkan dan menemukan asesmen alternatif yang valid, praktis dan efektif berlandaskan pembelajaran matematika dengan pendekatan realistik di Sekolah Dasar (SD).

\section{Metode Penelitian}

Model pengembangan yang digunakan dalam penelitian ini mengacu pada model pengembangan pendidikan dari Plomp (2001) dengan memperhatikan tiga aspek kualitas produk yang dikemukakan Nieveen. Tahapan pengembangan yang ditempuh meliputi dua tahap yakni tahap pra-pengembangan dan tahap pengembangan. Tahap pra-pengembangan terdari dari atas 3 fase yaitu: (1) fase investigasi awal, (2) fase perancangan, (3) fase realisasi, sedangkan tahap pengembangan meliputi fase tes, evaluasi dan revisi.

Uji coba meliputi uji coba terbatas dan uji coba diperluas yang sebelumnya dilakukan uji keterbacaan. Kegiatan uji coba ini dimungkinkan terjadi siklus sampai diperoleh prototipe yang memenuhi kriteria kevalidan, kepraktisan, dan keefektifan. Prototipe yang memenuhi kriteria tersebut disebut prototipe ke-n yang merupakan produk akhir hasil pengembangan.

Subjek coba dalam penelitian ini adalah siswa SD kelas IV yang terdaftar pada tahun pelajaran 2009/2010 dan guru matematika kelas IV SD. Sebaran siswa dan guru yang dijadikan sebagai subjek coba dalam penelitian ini disajikan pada Tabel 2.

Tempat uji coba keterbacaan dan uji coba terbatas adalah SDN Timbulharjo. Sedangkan tempat uji coba diperluas adalah SDN Timbulharjo, SDN Gambiranom, dan MIN Yogyakarta II. Setiap kelas/sekolah melibat- 
kan 3 orang guru yakni 1 (satu) orang untuk mengampu pembelajaran dan 2 (dua) orang sebagai pengamat untuk keperluan penelitian ini.

Tabel 2. Sebaran Subjek Penelitian

\begin{tabular}{ccccc}
\hline \multirow{2}{*}{$\begin{array}{c}\text { Jenis } \\
\text { Subjek }\end{array}$} & \multicolumn{3}{c}{ Jumlah Subjek Uji Coba } & \multirow{2}{*}{ Jumlah } \\
\cline { 2 - 4 } & Keterbacaan & Terbatas & Diperluas & \\
\hline Siswa & 33 orang & 40 orang & 119 orang & 192 orang \\
Guru & 10 orang & 3 orang & 9 orang & 22 orang \\
\hline
\end{tabular}

Data dalam penelitian ini merupakan data kuantitatif dan kualitatif. Data kuantitatif meliputi: kemampuan siswa dalam pemecahan masalah matematika yang diperoleh melalui penyelesaian Tugas PR, penilaian diri siswa terhadap tugasnya, data aktivitas siswa selama pembelajaran di kelas. Data kualitatif adalah data hasil validasi oleh ahli/praktisi terhadap asesmen alternatif dalam pembelajaran matematika realistik.

Ada dua macam instrumen yang digunakan dalam penelitian ini, yaitu instrumen pengumpul data selama validasi dan instrumen pengumpulan data selama pengembangan. Instrumen pengumpulan data tersebut, meliputi: (a) perangkat asesmen, dan (b) instrumen penelitian.

Perangkat asesmen terdiri atas: (1) Perangkat Asesmen Aktivitas Siswa (AAS) (2) Perangkat Asesmen/Penilaian Diri Siswa(PDS), dan (3) Perangkat Asesmen Kemampuan Pemecahan Masalah (AKPM) dan instrumen penelitian terdiri atas: (1) Lembar Penilaian Asesmen Alternatif (2) Lembar Pengamatan Keterlaksanaan Asesmen Alternatif, (3) Angket Keefektifan Asesmen alternatif, (4) Lembar Pengamatan Aktivitas Siswa, (5) Lembar Pengamatan Aktivitas Guru, (6) Angket Respons Siswa, (7) Rencana Pembelajaran, dan (8) Lembar Validasi

Validitas dan reliabilitas instrumen-instrumen yang digunakan, dilakukan tindakan validasi instrumen dengan prosedur (tahapan) pengembangan yang mengacu pada pendapat Cohen \& Swerdlik (2005: 190) dan Mardapi (2008: 108). Instrumen tugas PR ditinjau dari beberapa dimensi 
persyaratan alat ukur tes antara lain: reliabilitas, tingkat kesulitan, dan daya pembeda soal (Cohen \& Swerdlik, 2005: 212). Untuk menentukan koefisien reliabilitas tes digunakan rumus koefisien alpha dari Cronbach (Allen \& Yen, 1979: 83),

Instrumen tugas PR ditinjau dari beberapa dimensi persyaratan alat ukur tes antara lain: reliabilitas, tingkat kesulitan, dan daya pembeda soal (Cohen \& Swerdlik, 2005: 212). Untuk menentukan koefisien reliabilitas tes digunakan rumus koefisien alpha dari Cronbach (Allen \& Yen, 1979: 83). Hasil analisis uji coba instrumen Tugas PR yang dikembangkan memenuhi persyaratan reliabilitas instrumen, sehingga instrumen Tugas PR tersebut dapat digunakan dalam pengembangan berikutnya. Untuk memperoleh data kevalidan instrumen yang berbentuk format validasi, lembar observasi, dan angket diselidiki validitas teoritisnya melalui penilaian ahli/pakar termasuk instrumen Tugas PR.

Untuk mengukur tingkat reliabilitas antarpenilai (inter-rater reliability) terhadap hasil penilaian/validasi instrumen penelitian oleh para ahli (expert), Tingkat reliabilitas antarpenilai (inter-rater reliability) terhadap hasil penilaian/ validasi instrumen penelitian oleh para ahli (expert), dianalisis dengan statistik Coeffisien Cohen's Kappa (Cohen, 2001: 657; Wilkerson \& Lang, 2007: 271). dan Percentage of Agreements (Grinnell, 1988: 160; Nitko dan Brookhart 2007:80). Koefisien Kappa dalam penelitian ini diperoleh dengan bantuan program software SPPS. 15.0,

Analisis data dilakukan secara deskriptif-kualitatif dengan memberikan narasi yang logis sesuai dengan kepentingan penelitian. Di samping itu, data yang telah dikumpulkan dengan menggunakan instrumen-instrumen penelitian selanjutnya dianalisis secara kuantitatif dan kualitatif, dan diarahkan untuk menjawab pertanyaan "apakah asesmen alternatif dan perangkat asesmen yang dikembangkan sudah valid, praktis, dan efektif atau belum?" Kriteria yang digunakan untuk memutuskan bahwa instrumen memiliki tingkat kualitas produk yang memadai, jika mencapai tingkat kualitas produk minimal "valid, praktis, dan efektif'. 


\section{Hasil Penelitian dan Pembahasan}

Tahap pra-pengembangan, dihasilkan prototipe awal yang meliputi: perangkat-perangkat asesmen yang merupakan perangkat penilaian dalam pembelajaran matematika dengan pendekatan realistik dan instrumeninstrumen penelitian. Hasil tahap pengembangan adalah sebagai berikut: dihasilkan prototipe asesmen alternatif dan instrumen penelitian berdasarkan pertimbangan ahli/praktisi, semuanya memenuhi kriteria yang telah ditetapkan. Ini berarti bahwa secara konseptual asesmen alternatif memenuhi kriteria "valid, praktis dan efektif'. Adapun hasil uji coba terbatas sebagai berikut: (i) Hasil penilaian keterlaksanaan asesmen alternatif berada pada tingkat keterlaksanaan "kurang terlaksana" dengan skor rata-rata total 2,46, sehingga belum memenuhi kriteria "praktis". (ii) Hasil analisis data keefektifan asesmen alternatif belum memenuhi kriteria efektif yang meliputi: penilaian Keefektifan asesmen anternatif ditinjau dari aspek peningkatan kualitas proses pembelajaran di kelas berdasarkan hasil pengamatan aktivitas siswa diperoleh skor rata-rata total 2,41 dengan kategori "kurang" dan aktivitas guru diperoleh skor rata-rata total 2,60 dengan kategori "baik", dan penilaian keefektifan asesmen alternatif ditinjau dari peningkatan hasil belajar siswa berdasarkan hasil penilaian diri siswa diperoleh skor rata-rata total 1,09 dengan kategori "cukup" dan hasil penyelesaian Tugas PR diperoleh skor rata-rata total 1,37 dengan kategori "baik". Penilaian keefektifan asesmen alternatif ditinjau dari respons siswa dan guru terhadap penerapan asesmen alternatif di kelas masing-masing diperoleh skor rata-rata total 91,39 dan 3,15 dengan kategori cenderung "positif".

Hasil uji coba diperluas meliputi: (i) Hasil penilaian keterlaksanaan asesmen alternatif berada pada tingkat keterlaksanaan "terlaksana" dengan skor rata-rata total 2,72, sehingga memenuhi kriteria "praktis". (ii) Hasil analisis data keefektifan asesmen alternatif memenuhi kriteria efektif yang meliputi: penilaian keefektifan asesmen alternatif ditinjau dari aspek peningkatan kualitas proses pembelajaran di kelas berdasarkan hasil pengamatan aktivitas siswa dan aktivitas guru diperoleh masing-masing skor ratarata total 3,03 dan 3,08 dengan kategori "baik". Penilaian keefektifan ases- 
men alternatif ditinjau dari peningkatan hasil belajar siswa berdasarkan hasil penilaian diri siswa dan hasil penyelesaian Tugas PR masing-masing diperoleh skor rata-rata total 1,51 dan 1,51 dengan kategori "baik" dan skor dari waktu kewaktu mengalami peningkatan, dan penilaian keefektifan asesmen alternatif ditinjau dari respons siswa dan guru terhadap penerapan asesmen alternatif di kelas masing-masing diperoleh skor rata-rata total 93,84 dan 3,32 dengan kategori cenderung "positif".

Upaya untuk meningkatkan kualitas pendidikan matematika, salah satunya adalah melalui implementasi PMRI secara terus-menerus ditingkatkan kualitasnya, baik dari segi proses maupun hasil pembelajaran. Sebagai ujung tombak pelaksana asesmen dalam pembelajaran, para guru perlu memiliki keterampilan-keterampilan dalam melakukan penilaian yang tepat pada proses dan hasil pembelajaran siswanya. Guru harus memahami bukti-bukti yang menggambarkan kompetensi yang telah dicapai siswa sehingga mereka dapat diberikan penilaian yang tepat atas capaiannya. Karena itu, guru perlu memiliki informasi yang lengkap tentang kemampuan siswa yang dapat menjadi dasar (acuan) dalam tindak lanjut (follow-up) untuk pembelajaran selanjutnya.

Seorang guru harus memahami kriteria yang digunakan dalam penilaian dan terbiasa menggunakan perangkat asesmen yang tepat, sehingga akhirnya dapat memberi hasil penilaian yang objektif atas hasil pembelajaran siswanya. Oleh karena itu, diperlukan asesmen yang terus menerus (kontinu) tentang perkembangan kemampuan siswa selama mengikuti proses pembelajaran. Selain sifatnya kontinu, hasil asesmen selalu diberikan umpan balik (feedback) dan tindak lanjutnya (follow-up). Tuntutan akan keragaman metode asesmen pada pembelajaran di kelas menjadi penting, mengingat dengan menggunakan metode asesmen yang variatif akan memberikan informasi yang lebih lengkap dan lebih menjamin kualitas hasil asesmen.

Sebagai konsekuensi dari penerapan konsep pendidikan matematika realistik, maka dalam proses asesmen kemajuan siswa sudah selayaknya juga siswa dilibatkankan dalam penilaian. Keterlibatan siswa dalam asesmen dapat menjadi referensi bagi guru untuk mempertimbangkan penetapan nilai akhir siswa, sehingga dihasilkan suatu skor kemampuan yang objektif 
dan akurat tentang kompetensi yang dicapai siswa. Keterlibatan siswa dalam asesmen dapat membantu anak menjadi lebih bersemangat dalam belajar dan bekerja, lebih bertanggung jawab, lebih percaya diri, dan memiliki komitmen terhadap nilai-nilai kejujuran dan objektif yang merupakan dampak pengiring penerapan asesmen ini.

Melalui proses pengembangan dengan menggunakan prosedur pengembangan Plomp, yang meliputi: fase investigasi awal, fase desain, dan fase realisasi/konstruksi sebagai tahap pra-pengembangan, hingga diperoleh prototipe asesmen alternatif, sedangkan fase tes, evaluasi dan revisi adalah tahap pembentukan prototipe akhir yang merupakan tahap pengembangan asesmen, hingga diperoleh asesmen alternatif yang memenuhi kriteria valid, praktis, dan efektif. Untuk fase implementasi yang merupakan tindakan sosialisasi terhadap hasil pengembangan, diharapkan dapat diterapkan oleh praktisi di lapangan, yakni oleh siswa dan guru dalam proses pembelajaran matematika di kelas.

Penelitian ini menghasilkan produk pengembangan berupa asesmen alternatif yang memenuhi kriteria valid, praktis, dan efektif, yang diwujudkan dalam bentuk Perangkat Penilaian dalam Pembelajaran Matematika Realistik di Sekolah Dasar. Komponen utama asesmen alternatif ini adalah (a) Perangkat Asesmen Aktivitas Siswa (AAS), (b) Perangkat Penilaian Diri Siswa (PDS), dan (c) Perangkat Asesmen Kemampuan Pemecahan masalah (AKPM). Pembahasan terkait dengan produk pengembangan di atas dapat dikemukakan sebagai berikut.

Berdasarkan penilaian (validasi) oleh ahli dan praktisi pendidikan, prototipe awal asesmen alternatif yang dikembangkan dinyatakan dapat digunakan untuk melakukan penilaian proses dan hasil pembelajaran di kelas pada Sekolah Dasar. Namun, setelah dilakukan validasi empiris dalam uji coba terbatas, ditinjau dari keterlaksanaan asesmen alternatif belum terpenuhi. Di sisi lain, kriteria keefektifan asesmen alternatif yang dikembangkan sebahagian telah memenuhi kriteria yang ditetapkan, diantaranya ditandai oleh tercapainya peningkatan hasil belajar siswa, yakni kemampuan pemecahan masalah siswa yang bergerak membaik dari waktu ke waktu seiring dengan kegiatan penerapan asesmen alternatif. Dengan demikian, penerapan asesmen alternatif mempunyai dampak yang dapat memotivasi 
belajar siswa semakin meningkat dan aktivitas guru semakin baik dan intensif yang relevan dengan pembelajaran matematika realistik meskipun belum memenuhi kriteria efektif.

Setelah melalui uji coba diperluas, hasil pengembangan asemen alternatif dinyatakan memenuhi kriteria kevalidan, kepraktisan, dan keefektifan. Dengan demikian, dapat disimpulkan bahwa asesmen alternatif yang dikembangkan merupakan asesmen yang memiliki kualitas baik untuk diterapkan pada pembelajaran matematika dengan pendekatan realistik.

Hasil analisis kevalidan menunjukkan bahwa semua validator menyatakan asesmen alternatif yang dikembangkan dibangun atas landasan berpikir yang rasional dan teori-teori pendukung yang kuat dan relevan. Komponen-komponen asesmen memiliki keterkaitan secara konsisten. Hasil analisis kepraktisan menunjukkan bahwa asesmen alternatif yang dikembangkan memenuhi kriteria kepraktisan, baik secara konseptual teoritis maupun hasil uji empiris. Tingkat kepraktisan asesmen alternatif terlihat dari keterlaksanaan asesmen alternatif. Hasil analisis keefektifan asesmen alternatif menunjukkan bahwa asesmen alternatif memenuhi kriteria efektif. Tingkat keefektifan asesmen alternatif tergambar dari: (a) terjadinya peningkatan kualitas proses pembelajaran, (b) terjadinya peningkatan hasil belajar siswa, dan (c) adanya adanya respons positif dari siswa dan guru terhadap penerapan asesmen alternatif dalam pembelajaran matematika dengan pendekatan realistik di kelas.

Hasil uji coba penerapan asesmen ini, ternyata menghasilkan dampak pengiring dan dampak psikologik bagi siswa. Dampak pengiring dari penelitian ini, bahwa dengan penerapan asesmen alternatif pada pembelajaran matematika dengan pendekatan realistik di kelas dapat memberi dampak langsung maupun tidak langsung bagi pembentukan pengetahuan dan kemampuan guru dalam melakukan asesmen secara benar, tepat, akurat, dan objektif atas proses dan hasil pembelajaran dengan mengacu pada kriteria penilaian yang ditetapkan. Dengan penilaian yang komprehensip dan berkelanjutan yang diterapkan selama proses pembelajaran di kelas, guru memiliki referensi yang cukup untuk menetapkan nilai yang memenuhi rasa keadilan dan kepuasan bagi siswa atas prestasi yang dicapai selama mengikuti proses pembelajaran yang berlangsung di kelas. 
Penerapan asesmen alternatif pada pembelajaran yang berlangsung di kelas juga memberi dampak psikologik yang baik bagi siswa. Keterlibatan siswa di dalam proses asesmen dapat meningkatkan terjadinya interaksiinteraksi sosial dan saling percaya antara satu siswa dengan lainnya dan interaksi antara siswa dan guru. Persepsi siswa bahwa dengan keterlibatannya dalam kegiatan asesmen secara umum telah meningkatkan percaya diri mereka, tanggung jawab, dan motivasi. Dampak sosial lainnya adalah bisa terjadi saling kontrol antara hasil asesmen yang dilakukan oleh siswa dan yang dilakukan guru terhadap penilaian diri siswa, sehingga dihasilkan suatu penilaian yang valid, objektif, dan dapat diterima oleh kedua belah pihak yakni siswa dan guru.

Berdasarkan semua kajian di atas, dapat dinyatakan bahwa asesmen alternatif yang sudah dihasilkan baik secara teoritis maupun praktis, merupakan asesmen yang telah teruji kevalidan, kepraktisan dan keefektifannya, sehingga dapat dipertimbangkan sebagai asesmen alternatif yang cocok digunakan pada pembelajaran matematika dengan pendekatan realistik. Dengan demikian, asesmen alternatif yang dihasilkan telah teruji kevalidan, kepraktisan, dan keefektifannya baik secara teoritis maupun praktis, sehingga dapat digunakan dalam pembelajaran matematika sebagai upaya untuk meningkatkan kualitas pendidikan matematika.

\section{Simpulan}

Berdasarkan uraian hasil dan pembahasan diatas, dapat dirumuskan beberapa simpulan: (1) Asesmen alternatif yang dikembangkan berlandaskan pembelajaran dengan pendekatan realistik melalui penelitian pengembangan, yang ditempuh melalui dua tahap yakni tahap pra-pengembangan yang terdiri atas: (i) fase investigasi awal; (ii) fase perancangan desain; (iii) fase realisasi, dan tahap pengembangan meliputi fase tes, evaluasi, dan revisi dengan persyaratan kualitas produk: valid, praktis, dan efektif. (2) Asesmen alternatif yang valid, praktis, dan efektif yang dihasilkan berupa perangkat penilaian dalam pembelajaran matematika dengan pendekatan realistik. Perangkat penilaian tersebut terdiri atas: (i) Perangkat Asesmen Aktivitas Siswa (AAS); (ii) Perangkat Penilaian Diri Siswa (PDS); dan (iii) 
Perangkat Asesmen Kemampuan Pemecahan Masalah (AKPM), dan (3) Seluruh perangkat asesmen yang dihasilkan termasuk kategori sangat valid, praktis, dan efektif dapat meningkatkan kualitas proses dan hasil pembelajaran matematika yang cenderung meningkat, dengan kategori baik. Demikian juga, respons siswa dan guru terhadap penerapan asesmen alternatif yang cenderung positif.

\section{Saran}

Berdasarkan hasil penelitian diajukan saran-saran sebagai berikut: (1) guru SD, disarankan untuk memanfaatkan produk asesmen hasil pengembangan sebagai salah satu pedekatan asesmen dalam pembelajarannya, yang mana guru selama ini mengalami kesulitan dalam melakukan penilaian, khususnya penilaian dalam pembelajaran matematika dengan pendekatan realistic. (2) Desiminasi perangkat penilaian hasil pengembangan ini dapat disosialisasikan di sekolah-sekolah khususnya di SD seperti melalui Kelompok Kerja Guru (KKG).

\section{Daftar Pustaka}

Allen, M. J. \& Yen, W.M. (1979). Introduction to measurement theory. Monterey, CA: Brooks/Cole.

Borg, W.R. \& Gall, M.D. (1983). Educational research (4 ${ }^{\text {th }}$ ed.). New York: Longman.

Cohen, B. H. (2001). Explaining psychological statistics (2 ${ }^{\text {nd }}$ ed.). New York: John Wiley \& Sons.

Cohen, R. J. \& Swerdlik, M.E. (2005). Psychological testing and assessment: An introduction to test and measurement $\left(6^{\text {th }}\right.$ ed.). New York: McGraw Hill.

De Lange, J. (1987). Mathematics, insight and meaning. Utrecht: OW\&OC, Utrecht University. 
Freudenthal, H.. (1973). Mathematics as an educational task. Dordrecht: D. Reidel.

- (1981). Major problems of mathematics education. Educational Studies in Mathematics, 12, 133-150.

Grinnell, R.M. Jr. (1988). Social work research and evaluation (3 ${ }^{\text {rd }}$ ed.). Itasca: F.E.Peacock.

Hadi, Sutarto. (2005). Pendidikan matematika realistik dan implementasinya. Banjarmasin: Tulip.

Hatfield, M. M, Edwards, N.T., Bitter, G.G., et al. (2003). Mathematics methods for elementary and middle school teachers. New York: John Wiley \& Sons.

Herman, J. L., Aschbacher, P.R., \& Winters, L. (1992). A practical guide to alternative assessment. Alexandria, VA: ASCD.

Mardapi, Djemari. (2008). Teknik penyusunan instrumen tes dan non tes. Yogyakarta: Mitra Cendia Press.

Marpaung, Y. (2006). Karakteristik PMRI (Pendidikan matematika Realistik Indonesia). Mathedu Jurnal Pendidikan Matematika, Vol.1 No.1 Januari 2006: Surabaya: Program Studi Pendidikan Matematika PPs. UNESA.

Nitko, A. J., \& Brookhart, S. M. (2007). Educational assessment of students. Columbus, NJ: Merril.

Pearson Educational Development Group. (2003). Authentic assessment overview. Diambil pada tanggal 15 Maret 2007, dari http://www.pearsonatschool.com 
Plomp, T. (1997). Development research on/in educational development, Enschede: Twente University.

. (2001). Development research on/in educational development, Enschede: Twente University.

Ratini, Rumgayatri, \& Siti Mustaqimah. (November 2001). Pengalaman dalam melaksanakan uji coba pembelajaran matematika secara realistik di MIN Yogyakarta II. Makalah disajikan dalam Seminar Nasional Pendidikan Matematika Realistik Indonesia, di Universitas Sanata Dharma.

Reys, R. E., Suydam, M. N., Lindquist, M. M., et al. (1998). Helping children learn mathematics. Englewood Cliffs, NJ.: Prentice-Hall.

Ter Heege, H. (1978). Testing the maturity for learning the algorithm of multiplications. Educational Studies in Mathematics, 9, 75-83.

Van den Heuvel-Panhuizen, M. (1996). Assessment and realistic mathematics education. Utrecht: Freudenthal Institute

Wilkerson, J. R. \& Lang, W. J. (2007). Assessing teacher competency: Five standards-based steps to valid measurement using the CAATS Model. Thousand Oaks, CA: Corwin Press. 